\title{
Jonge stotterende kinderen: Klinisch redeneren met behulp van een praktijkgericht stroomschema
}

\author{
Marlies S. Tonnis ${ }^{1}$, Joeri van Ormondt ${ }^{2}$ \\ ${ }^{1}$ Stottercentrum Noord, Assen, Groningen \\ ${ }^{2}$ De Stotterpraktijk, Amstelveem, Arnhem, IJmuiden, Purmerend
}

\begin{abstract}
Samenvatting
Bij jonge stotterende kinderen is er een specifieke periode van ongeveer twee jaar om het kind te helpen naar vloeiendheid. Na aanmelding moet worden ingeschat hoe groot de kans is op natuurlijk herstel en er dus niet direct behandeld hoeft te worden. Hier is een belangrijke rol weggelegd voor de logopedist. Op basis van wetenschap geeft de Richtlijn Stotteren (NVLF, 2020) handvatten. In dit artikel vertalen we dit naar de klinische praktijk. We focussen op een aantal therapiekeuzes en vooral op het afwegen van de risicofactoren voor blijvend stotteren en hoe de logopedist het traject van monitoren praktisch vorm kan geven.
\end{abstract}

\begin{abstract}
Summary
In young children who stutter, there is a specific period of approximately two years to guide the child to fluency. The speech therapist must assess the chance whether natural recovery will occur and conclude if immediate treatment is required. The speech therapist plays an important role in this decision making process. Based on science, the Guideline Stuttering (NVLF, 2020) provides recommendations. In this article we translate this into clinical practice. We focus on the choices the speech therapist needs to make regarding therapeutic interventions, weighing the risk factors for persistent stuttering and elaborate how the speech therapist may give practical shape to monitoring procedure.
\end{abstract}

\section{Inleiding}

Bij jonge stotterende kinderen is er een specifieke periode om het kind te begeleiden naar vloeiendheid. In de eerste twee jaar na de eerste stottermomenten heeft het kind grote kans

Correspondentieadres:

Marlies S. Tonnis

Stottercentrum Noord, Assen, Groningen

E-mail: info@stotterconnect.nl
Dit artikel is gelicentieerd onder de Creative Commons CC BY-NC-ND 4.0 (NaamsvermeldingNietCommercieel-GeenAfgeleideWerken) Internationale Licentie. Gebruik en distributie voor commerciële doeleinden en elke distributie van aangepast materiaal vereist schriftelijke toestemming. 
van het stotteren te herstellen. Daarna neemt die kans snel af naar 16 procent drie jaar na aanvang (Yairi \& Seery, 2011). Een behandeltraject neemt snel een jaar in beslag en ouders komen lang niet altijd direct na de eerste stottermomenten. Logopedist en ouders kunnen deze (behandel)kans om te herstellen van stotteren aangrijpen.

Monitoren, behandelen, risicofactoren, lijden, zorgen, blijvend stotteren, normale onvloeiendheid, combinatie met articulatie- of taaltherapie; het is niet altijd makkelijk dit alles helder op een rijtje te krijgen bij jonge stotterende kinderen. In dit artikel doorlopen we alle stappen die een logopedist volgens de herziene Richtlijn Stotteren (NVLF, 2020) zou moeten nemen bij een jong kind dat stottert. Van aanmelding tot het afsluiten van het dossier, alle afwegingen presenteren we in een overzichtelijk stroomschema. In het artikel wordt een duidelijke koppeling met de praktijk gemaakt. De focus van dit artikel ligt met name op de weging van risicofactoren en de invulling van monitoren, omdat deze aanpak relatief nieuw is binnen de behandeling van jonge stotterende kinderen. Na het lezen van dit artikel hebben ook logopedisten die deze doelgroep niet zo vaak zien kennis over handelen volgens de richtlijn.

\section{De eerste stappen}

De meeste ouders zullen contact opnemen met de logopedist omdat zij bij hun kind onvloeiendheden horen in het spreken. Het komt ook voor dat deze door bijvoorbeeld een leerkracht gehoord worden. De timing van contact opnemen verschilt per ouder(paar). De ene ouder belt spoedig nadat de onvloeiendheden voor het eerst opvielen, anderen kijken het eerst een tijdje aan. We horen nog regelmatig dat het -achterhaalde- advies 'wacht maar af, het gaat wel over' gegeven wordt. Door familieleden; maar ook huisartsen en jeugdartsen geven nog regelmatig dit advies. Ook zijn er ouders die dit zelf denken of twijfelen of het wel om stotteren gaat. Door te wachten met aanmelden verstrijkt er soms onnodig veel tijd en kan het stotteren zich zodanig ontwikkelen dat er sprake is van lijden bij het kind. We maken na aanmelding altijd een afspraak, omdat uit ervaring blijkt dat het bijna zonder uitzondering om stotteren gaat.

Ouders voelen vaak goed aan (Tumanova et al., 2018) of hun kind stottert. Ze maken onbewust het onderscheid tussen stotteren en normale onvloeiendheid. Uiteraard is het de taak van de logopedist de diagnose 'stotteren' te stellen. Op pagina 30 van de Richtlijn Stotteren (NVLF, 2020) staat dit verschil uitgelegd. De mate van onvloeiendheid is niet in elke situatie hetzelfde. Het komt regelmatig voor dat het kind in de behandelkamer veel vloeiender spraak laat horen. Dit maakt het stellen van een diagnose lastig(er). Het spreken kan thuis heel anders zijn, daarom is het van toegevoegde waarde als ouders filmpjes maken in verschillende situaties. Ook kunnen ouders gerichte observatieopdrachten krijgen om meer gerichte informatie te verzamelen.

Ouders vinden het vaak prettig van tevoren te weten dat de logopedist het onderscheid 
tussen stotteren en normale onvloeiendheid kan maken. En dat behandeling niet nodig is in geval van het laatste, omdat het passend is binnen de normale taalontwikkeling. Nog één controleafspraak een aantal weken later is vaak aan te raden, om zo de ontwikkeling van het onvloeiende spreken iets langer te volgen.

\section{Van intake tot oudergesprek}

Tijdens intake en onderzoek is het essentieel om de risicofactoren (zie paragraaf 2.3 van dit artikel), de reactie van het kind op het stotteren en de bezorgdheid van ouders in kaart te brengen. Daarnaast kan een anamnese-vragenlijst zoals Guitar (2014) die heeft opgenomen in zijn boek (hoofdstuk 9 van de vierde editie) worden afgenomen. Ook is het belangrijk eventuele meertaligheid uit te vragen.

Tijdens een daaropvolgend oudergesprek bespreekt de logopedist de uitkomsten van de onderzoeken. Ouders en logopedist maken samen de afweging te monitoren of te behandelen. Ze doen dit op basis van de volgende drie afwegingen. Of het kind onder het stotteren lijdt, de bezorgdheid van ouders en de risicofactoren. Als wordt gekozen voor behandelen, dan wordt door de Richtlijn Stotteren (NVLF, 2020) aanbevolen een keuze te maken tussen het Lidcombe Program of RESTART-DCM. Om tot gezamenlijke besluitvorming te komen is het belangrijk dat de logopedist de ouders informatie geeft over beide behandelmethodes. Vaak is deze sessie ook een geschikt moment om meer informatie over de ontwikkeling van stotteren te geven.

\section{Kind lijdt onder stotteren}

Doorgaans zeggen jonge kinderen niets over het stotteren. Daardoor lijkt het alsof ze het niet doorhebben. Dat kinderen zelf het stotteren benoemen is op het continuüm van bewustzijn (Waelkens, 2018) pas de laatste stap. Het bewustzijn begint volgens Waelkens met frustratie op het moment van controleverlies. Het kind wordt als het ware overvallen door de stotter. Op andere momenten is het kind zich bewust dat hij stottert. Vervolgens kan het kind het controleverlies gaan herkennen, eerst tijdens en daarna net voor het controleverlies. Tenslotte is er de laatste fase, het verbaliseren. Het kind kan zich dus al veel eerder bewust zijn van het stotteren, dan het moment dat het erover praat. Het is zeer belangrijk dit in het assessment mee te nemen en goed in kaart te brengen.

Secundair stottergedrag geeft inzicht in de mate van bewustzijn en is een belangrijke indicator om te inventariseren of het kind onder het stotteren lijdt. Een aantal voorbeelden:

- Een kind dat halverwege een zin stopt met praten en zegt: "ik weet het niet meer".

- Minder vaak iets vertellen of in kortere zinnen praten

- Het gebruiken van andere stemmetjes

- Aanwijzen in plaats van iets benoemen 
- Snel van woord wisselen binnen een zin

- Veel fluisteren

- Meebewegen met (delen van) het lichaam of gezicht

- Spanning in of rond de articulatoren

Als één of meerdere van deze voorbeelden een aantal weken duidelijk aanwezig zijn in het spreken, duidt dit meestal op 'lijden onder stotteren'. De Richtlijn is dan duidelijk; aanbeveling 3: behandelen niet (langer) uitstellen.

\section{Zorgen bij ouders}

Als ouders het stotteren van hun kind belastend vinden of zorgen hebben, is het volgens aanbeveling 3 van de Richtlijn reden om de behandeling te starten. Door zorgen die ouders hebben, kunnen ze op een onhandige manier op het stotteren (gaan) reageren. Zoals spreektips geven die het kind eerder zullen frustreren dan helpen. Het is de taak van de logopedist om te proberen, door uitleg te geven over stotteren, de zorgen bij ouders weg te nemen. Dit kan bijvoorbeeld gebeuren tijdens het oudergesprek. Zijn er daarna nog steeds zorgen, of hebben ouders geen vertrouwen in een beleid van monitoren, dan is behandelen de aanbevolen route.

\section{Risicofactoren}

De logopedist brengt alle risicofactoren in kaart. Hieronder sommen we de risicofactoren op zoals die genoemd zijn in paragraaf 3.3.1 van de herziene Richtlijn Stotteren (NVLF, 2020) en interpreteren ze. We sluiten dit hoofdstuk af met het wegen van de verschillende risicofactoren.

\section{Zwaarwegende risicofactoren}

Blijvend stotteren in de familie

Volgens de Richtlijn is blijvend/persisterend stotteren in de familie de sterkste voorspeller voor persisteren van stotteren bij het kind, zoals is gevonden in de Illinois-studie (Yairi \& Ambrose 2005; Seery \& Yairi 2015). Het verloop van het stotteren heeft de grootste kans om het patroon in de familie te volgen. Indien blijvend stotteren in de familie voorkomt, is de kans dat het kind zonder behandeling blijft stotteren 65 procent. Bij aanwezigheid van hersteld stotteren in de familie van het kind is juist de kans op natuurlijk herstel bij het kind 65 procent. Vraag dus altijd of er een (of meerdere) familielid is die al zijn hele leven stottert. Soms is het nodig hierbij door te vragen, omdat het gebruiken van vermijdingsstrategieën vaak niet als stotteren herkend wordt. Een vader zegt dan bijvoorbeeld "als ik moe ben heb ik er nog last van". Bij goed luisteren hoor je dan vaak ook wel wat onvloeiendheden in de spraak van de betreffende vader. Ook geven we vaak voorbeelden als het eerste antwoord 'nee' is: "neefjes, nichtjes, opa, enzovoort?" Daarnaast is het ook belangrijk om uit te vragen 
of er op jonge leeftijd wel stotteren was bij een familielid, en dat dit er nu niet meer is. Voorbijgaand stotteren in de familie maakt de kans voor de cliënt groter dat het stotteren over gaat.

\section{Het kind is vijf jaar of ouder}

Behandeling van kinderen tot en met de kleuterleeftijd is effectiever dan behandelen op latere leeftijd (Richtlijn Stotteren, 2020, pag 54). Hierdoor is het bij kinderen die met 4;7 jaar zijn begonnen met stotteren niet verstandig om nog 12 maanden te monitoren. Dan dient de behandeling eerder te starten.

\section{Het kind is een jongen}

Bij kinderen die beginnen te stotteren is er niet veel verschil in de ratio jongens versus meisjes. Op latere leeftijd zijn er veel meer jongens die stotteren dan meisjes. Bij meisjes gaat stotteren dus vaker over en jongens lopen meer kans te blijven stotteren.

\section{Het stotteren bestaat al een jaar of langer zonder duidelijke verbetering}

Voor deze risicofactor is het nodig om het moment te achterhalen van de allereerste stotters, ongeacht of het stotteren een tijd weggeweest is. De ervaring leert dat ouders dit soms lastig vinden te achterhalen. Vaak helpt het om belangrijke punten uit te vragen, zoals "hoe was het op vakantie?" of "was er al wat stotteren met kerst?" Filmpjes kunnen soms ook helpen dit in kaart te brengen. Het is belangrijk om een duidelijk beeld te krijgen van de stotterernst na de start en in deze eerste periode. Dit wordt verderop in het artikel verder toegelicht. Hoe langer er stotteren is zonder dat het in het spoor van natuurlijk herstel komt, hoe kleiner de kans dat het nog overgaat. De Richtlijn schrijft er het volgende over: "Kort nadat de eerste stottersymptomen zijn waargenomen, is de kans op natuurlijk herstel groot, (...) 79 procent. Als de kinderen reeds één jaar stotterden was de kans afgenomen tot $63 \%$, als ze reeds twee jaar stotterden tot $47 \%$, als ze reeds drie jaar stotterden tot $16 \%$ en als een kind reeds vier jaar stotterde was de kans op herstel zonder behandeling nog slechts 5\%" (pag 43-44). Yairi en Seery (2015) hebben in hun boek (pagina 104) een overzichtelijke grafiek hiervan opgenomen.

\section{Overige risicofactoren}

\section{Zwakke fonologische of spraakmotorische vaardigheden}

De logopedist kan een eerste indruk krijgen op haar gehoor tijdens het observeren van spontane spraak. Daarnaast zijn er diverse gestandaardiseerde onderzoeksmethoden om deze vaardigheden in kaart te brengen. Ook kan gedacht worden aan de OMAS (Riley \& Riley, 1985), die het al dan niet aanwezig zijn van een spraak-motorische discoördinatie in kaart brengt. In paragraaf 2.4 van dit artikel staat de mogelijke interactie van articulatietherapie en stotteren beschreven. 
Zwakke taalontwikkeling of juist over een langere periode een bovengemiddelde taalontwikkeling samen met stotteren

Een onder- of bovengemiddeld taalniveau is ook een risicofactor voor stotteren. Eenduidige resultaten uit onderzoek zijn er echter nog niet. Omdat we taal vaak als uitlokkende factor zien voor stotteren, nemen we de genormeerde taalscores mee in de risicofactoren als hier aanleiding voor is. Het is hierbij belangrijk ook de passieve woordenschat te meten. Het kan een boven- of ondergemiddeld taalniveau van het kind zijn of significante verschillen tussen de taalmodaliteiten. We nemen daarvoor bij elk kind waar twijfels zijn over het taalniveau genormeerde taaltesten af om de passieve en actieve taalvaardigheid in kaart te brengen.

\section{Temperamentskenmerk negatieve reactiviteit}

Temperament (en emotie) is een belangrijke trigger voor stotteren. We horen vaak ouders zeggen: "Ons kind reageert snel enthousiast en dan stottert hij meer." Temperament is een beperkte risicofactor voor blijvend stotteren. Het is goed in kaart te brengen met de CBQ (Rothbart et al., 2001) -very short Dutch. Dit is een vragenlijst voor ouders met 36 vragen. Met name de subschaal negatieve affectiviteit is een voorspeller gebleken voor blijvend stotteren.

Aanwezigheid van bijkomende stoornissen

Naast het stotteren kan er sprake zijn van bijkomende stoornissen, zoals autisme of ADHD. Of de aanwezigheid van een bijkomende stoornis de kans op blijvend stotteren vergroot, is onbekend. Wel kan het invloed hebben op het stotteren en de stotterervaring van het kind, daarom is het belangrijk dit mee te nemen in het klinisch redeneren.

\section{Weging risicofactoren}

Hoe meer risicofactoren er zijn, hoe eerder wordt overgegaan op behandelen. Bij drie zwaarwegende risicofactoren (of meer) start de logopedist zo vroeg mogelijk de behandeling (NVLF, 2020). Als er geen risicofactoren zijn, wordt de behandeling gestart als de stotterernst negen tot twaalf maanden na het ontstaan van stotteren niet duidelijk is afgenomen. De afname dient vergeleken te worden met de stotterernst kort na het ontstaan van het stotteren (aanbeveling 1). Bij de aanwezigheid van één of meerdere risicofactoren wordt de tijd dat er gemonitord wordt, verkort. De Richtlijn Stotteren (NVLF, 2020) geeft niet aan hoeveel korter het monitoren duurt bij een bepaald aantal risicofactoren. Logopedist en ouders bepalen de duur van het monitoren in overleg tijdens het oudergesprek. Dit wisselt van kind tot kind.

De auteurs van dit artikel hebben in overleg met de hoofdauteur van het hoofdstuk 'Indicaties' van de Richtlijn Stotteren (NVLF, 2020) voor de dagelijkse praktijk de volgende handvatten geformuleerd: één zwaarwegende factor staat voor een verkorting van zo'n drie maanden. Twee van de overige risicofactoren kunnen samen geïnterpreteerd worden als vergelijkbaar met één zwaarwegende factor. De weging van de risicofactoren blijft maatwerk. Bij twijfel start de behandeling uiteraard liever eerder dan later. Natuurlijk kan ook altijd een logopedist-stottertherapeut worden geraadpleegd. 


\section{Hoe te handelen bij bijkomende logopedische stoornissen}

Aanbeveling 5 van de Richtlijn stelt: "Gelijktijdige aanwezigheid van stotteren en een taalontwikkelingsstoornis mag niet leiden tot vertraging van een geïndiceerde stottertherapie." Stottertherapie kan dus niet wachten. Dit heeft alles te maken met de relatief korte periode waarin het stotteren nog helemaal over kan gaan. Gelijktijdig behandelen van stotteren en TOS levert vaak een te grote druk op zowel ouders als het spraaksysteem van het kind. Meer stotteren is dan dikwijls het gevolg. Het is dan verstandig voor uitsluitend stottertherapie te kiezen.

Hetzelfde geldt voor articulatietherapie. Ook hier wordt, met name door oefeningen gericht op productie, het spraaksysteem als het ware overbelast. Dat heeft vaak meer of ernstiger stotteren tot gevolg. Er is weinig onderzoek naar gedaan, maar experts als Scott Yaruss (Reitzes, 2017) en het Michael Palin Centre (Kelman \& Nicolas, 2020) zijn het erover eens dat stottertherapie meestal voor dient te gaan op articulatietherapie. Een (beperkt) onderzoek van Unicomb et al. (2016) wijst ook in die richting.

\section{Monitoren}

In de Richtlijn gaan de sterke aanbevelingen 1, 2 en 3 over monitoren en de afwegingen die daarbij gemaakt moeten worden. In onderstaande tekst wordt de praktische handreiking, die in de Richtlijn is opgenomen, verder uitgewerkt. Als er vanuit intakegesprek, onderzoek, in kaart brengen van zorgen ouders en lijden van het kind, en de weging van de risicofactoren blijkt dat er nog geen indicatie is om direct de behandeling te starten, maken logopedist en ouders afspraken om te monitoren.

Het doel van monitoren is dat gedurende een aantal maanden de ontwikkeling van het stotteren actief wordt gevolgd. De reden hiervoor is de kans op natuurlijk herstel. De logopedist heeft de verantwoordelijkheid om alleen zorg te verlenen indien dit noodzakelijk is, dit zowel in verband met de belasting van ouders/gezin als ook de zorgkosten. Wel is het belangrijk de ontwikkeling van het stotteren te blijven volgen, om direct in te kunnen grijpen als dat nodig blijkt. Hier is de periode van monitoren voor.

\section{Ernstscore}

Tijdens het proces van monitoren kun je ernstscores gebruiken. In de Richtlijn Stotteren staat de 8-puntsschaal voor stotterernst van Yairi en Ambrose (2015) genoemd. Ook de 10-puntsschaal voor stotterernst behorende bij het Lidcombe Programma kan hiervoor gebruikt worden. Om ouders hierin te kunnen trainen is het belangrijk dat de logopedist betrouwbaar de ernstscores kan bepalen. Binnen de cursussen gericht op het behandelen van stotteren bij jonge kinderen wordt hier aandacht aan besteed. Het is belangrijk dat er een zekere eenduidigheid in bestaat en dat de logopedist er een interne consistentie in heeft. 
De scores van de ouders worden hier namelijk op gebaseerd. De stotterernst wordt bepaald door een aantal zaken: de frequentie van het stotteren (hoe vaak het kind stottert), de duur van de stottermomenten en de manier van stotteren. In gesprekken leert de logopedist de ouders om deze zaken te herkennen en er een score aan te geven. Het is belangrijk dat ouders hier bekwaam in worden, omdat hiermee de veranderingen in het stotteren tijdens het monitoren worden gevolgd.

\section{Trend}

Tijdens het monitoren houden ouders de stotterernst bij op de manier die ze geleerd hebben. Dit doen ze door dagelijks de score te bepalen en te noteren. Tijdens een één- tot driemaandelijkse afspraak stemmen ouders en logopedist de ernstscores af. Het is belangrijk dat de scores weer met elkaar geijkt worden, om te zien of de door ouders gegeven scores overeenkomen met de observaties van de logopedist. Tijdens de afspraak kijkt de logopedist naar de trend van de ernstscores; nemen de scores toe, af of blijven ze gelijk.

Naast de ernstscores voert de logopedist (idealiter) 3, 6 en 9 maanden na het ontstaan van het stotteren een herhalingsonderzoek uit. Een herafname van de SSI-4 van een representatief sample kan worden overwogen.

\section{Afweegmoment}

Tijdens de afspraken bespreekt de logopedist elke keer of ouders aanwijzingen hebben of het kind onder het stotteren lijdt, of er minder door spreekt. Het is belangrijk om hier een aantal voorbeelden van te bespreken met ouders, zodat zij weten op welk gedrag zij moeten letten bij hun kind. Zodra hier een verandering in zichtbaar is, gaat het monitoren over in behandelen. Ten tweede wordt de stotterernst bepaald en worden de ernstscores van ouders vergeleken met die van de logopedist. De zorgen van ouders zijn een derde terugkerend punt tijdens deze gesprekken. Als deze toenemen en ze niet kunnen worden weggenomen in een oudergesprek is dat ook reden om over te gaan op behandelen. Elke afspraak is een nieuw afweegmoment. De logopedist bekijkt de aanwezige risicofactoren en bepaalt samen met ouders of monitoren nog de juiste route is. In overleg met ouders wordt opnieuw bepaald hoe het monitoren vervolgd wordt of dat het punt is bereikt waarbij het meer verantwoord is om behandeling te starten.

\section{Adviezen}

Er wordt aangeraden terughoudend te zijn met tips voor thuis. In de handreiking monitoren (Richtlijn Stotteren, NVLF 2020, pag 51) staat: "Nieuw gedrag moet worden voorgedaan en geoefend en dat vergt therapie. Ouders kunnen zich schuldig voelen als ze de tips thuis niet kunnen toepassen en dat zou eerder een verergering van het stotteren kunnen geven." De auteurs van dit artikel hebben in overleg met de auteurs van de handreiking monitoren voor 
de dagelijkse praktijk de volgende handvatten geformuleerd: Eén advies richt zich op vloeiendheidbevorderend gedrag dat ouders uit zichzelf al gebruiken en vaker/bewuster kunnen toepassen; bijvoorbeeld rustig blijven luisteren naar hun kind als het stottert. Het tweede advies richt zich op een aanpassing in het gedrag dat helpend kan zijn voor het kind; bijvoorbeeld het meer afbakenen van spreekmomenten tijdens eetmomenten als er meer kinderen in het gezin aanwezig zijn. Een ander voorbeeld is het advies om geen spreektips meer aan het kind te geven, maar gericht te blijven luisteren naar wat het kind zegt. De adviezen dienen passend te zijn bij het kind en zijn/haar ouders.

Het is belangrijk om een duidelijk onderscheid te maken tussen het monitoren en behandelen. Het advies moet zo helder zijn dat ouders er thuis direct iets mee kunnen, zonder dat ermee geoefend wordt tijdens een afspraak.

\section{Duur}

De initiële periode van monitoren duurt maximaal 12 maanden na de eerst aanwezigheid van stotteren in het spreken van het kind en is daardoor mede afhankelijk van het moment van aanmelden. Er zijn weinig ouders die de dag na de eerste stottermomenten hun kind aanmelden bij de logopedist. Uit het intakegesprek komt naar voren hoe lang het stotteren al aanwezig is. Als de aanvang 4 maanden geleden was is de periode van monitoren nog maximaal 8 maanden. De logopedist probeert voor die 4 maanden de stotterernst zo goed mogelijk in beeld te krijgen. Ouders kunnen met terugwerkende kracht een globaal beeld geven van de ernstscores en soms is het mogelijk met behulp van video-opnames een goed beeld te krijgen van het spreken in deze periode.

Eén van de zwaarwegende risicofactoren is de duur sinds de eerste stottermomenten en de tendens van de stotterernst in deze periode. De kans op natuurlijk herstel is het grootst in het eerste jaar na aanvang van het stotteren en bij ieder kind wil de logopedist de kans inschatten op natuurlijk herstel. Tijdens de periode van monitoren kijkt de logopedist of er een dalende trend is in de stotterernst. Bij een duidelijke afname (zie aanbeveling 1 Richtlijn Stotteren, NVLF 2020) van de stotterernst sinds de start van het stotteren lijkt een trend van natuurlijk herstel ingezet. In dat geval wordt de periode van monitoren verlengd. In de gesprekken met ouders evalueert de logopedist of de trend verder doorzet. Als de afname stagneert of er is een toename in stotterernst, dan start de behandeling alsnog.

Het is belangrijk het monitoringtraject niet te vroeg te stoppen. Pas nadat er 12 maanden geen stotteren in het spreken is gehoord, is er sprake van 'hersteld stotteren'. De logopedist blijft hierom in een ideale situatie gedurende een jaar na het herstel van de vloeiende spraak het spreken van het kind volgen met laagfrequente afspraken. Als het stotteren gedurende 12 maanden afwezig blijft kan het traject worden afgesloten.

Als er geen dalende trend zichtbaar is in de stotterernst (dus als deze gelijk blijft of toeneemt), is dit reden om over te gaan op behandelen 9 tot 12 maanden na aanvang van het 
stotteren. Uiteraard kan de behandeling ook eerder starten als de weging met andere risicofactoren hier aanleiding toe geeft, de zorgen van ouders toenemen of als het kind begint te lijden onder het stotteren.

\section{Behandelen}

Bij behandelen dient de logopedist in overleg met ouders een keuze te maken tussen het Lidcombe Programma of de RESTART-DCM behandeling (aanbeveling 8). Beide behandelprogramma's hebben 18 maanden na aanvang van de behandeling een even hoge effectiviteit, blijkt uit onderzoek (De Sonneville-Koedoot et al., 2015). Theoretisch maakt het dus niet uit welke gekozen wordt. Het is aan te raden de therapie zoveel mogelijk bij het kind en bij het gezin aan te laten sluiten. Daarom is overleg met de ouders over de te kiezen therapie een sterke aanbeveling in de Richtlijn. Het is de taak van de logopedist om de ouders informatie te geven over beide methodes, om zo tot gezamenlijke besluitvorming te kunnen komen.

Eenmaal gekozen is het belangrijk dat de logopedist het programma op de juiste manier aan kan bieden. Het volgen van bij- en nascholing is hiervoor een vereiste. DCM wordt in de meeste basis HBO-opleidingen aangeboden, echter slechts zeer beperkt. De driedaagse basiscursus RESTART-DCM is nodig om de methode op de correcte wijze vorm te geven. RESTART-DCM bouwt volgens een schema van vier domeinen en drie fasen de behandeling op. Ook is er in de cursus veel aandacht voor klinisch redeneren; 'wat heeft dit kind nu nodig'. Naast de basiscursus zijn er nog een keur aan bijscholings- of verdiepingscursussen om een stap verder te kunnen gaan in de behandeling. Dit is vaak handig als volledige vloeiendheid met de basis-elementen niet behaald wordt. Er zijn vervolgcursussen op het gebied van het spraak-motorische en emotionele domein. Ook kan de logopedist bijvoorbeeld MiniKIDS volgen om een meer directe therapieaanpak (laatste stap binnen RESTART-DCM) aan te kunnen bieden. Indien de logopedist geen verdiepingscursussen heeft gedaan en de cliënt dit wel nodig heeft, kan de logopedist altijd doorverwijzen naar een logopedist die deze cursussen wel heeft gevolgd.

Om een kind te behandelen met het Lidcombe Programma is ook een cursus vereist. Ook bij dit programma is het noodzakelijk de stappen aan te houden en de verschillende aspecten correct aan ouders te bieden.

Het is aan te raden beide methoden aan te kunnen bieden. Voor ouders is het een belemmering als ze voor de methode van hun keuze naar een andere logopedist moeten. Ook is het zaak (in het licht van de Richtlijn) ze beide voldoende uit te kunnen leggen.

Tijdens de behandeling kan de vooruitgang in vloeiendheid in kaart gebracht worden met de (Richtlijn Stotteren hoofdstuk 3) beschreven ernstscores. Gedurende het behandeltraject moet een dalende lijn te zien zijn in de stotterernst. Soms gaat dit met pieken en dalen, maar de trendlijn moet dalend zijn. Op het moment dat er vloeiendheid is bereikt, is het belangrijk om nog gedurende geruime tijd tijdens controle-afspraken te kijken of deze 
vloeiendheid behouden blijft. Dit staat ook beschreven in de werkwijze van de therapieprogramma's.

Elke drie maanden hebben logopedist en ouders een evaluatie van de behandeldoelen. De doelen moeten voldoende gerealiseerd worden (aanbeveling 21). Gedurende de eerste drie maanden van therapie dient ook een significante verbetering in het stotteren op te treden (aanbeveling 20). Als dit niet het geval is in één van beide gevallen dient een collega met meer expertise te geraadpleegd te worden.

Er is een groep kinderen waarbij natuurlijk herstel niet optreedt en waarbij middels behandeling ook geen vloeiende spraak bereikt wordt. In de drie-maandelijkse evaluaties zal dit dan naar voren komen. Uiteraard dient de logopedist hulp in te schakelen van een collegalogopedist(-stottertherapeut) of door te verwijzen naar een andere discipline als daar aanwijzingen voor zijn.

\section{Bijstellen behandeldoel}

De logopedist heeft de verantwoordelijkheid om binnen de eigen grenzen het uiterste te doen om een jong kind dat stottert te begeleiden en indien nodig door te verwijzen. Daarnaast kan de logopedist bijdragen aan het beperken van de invloed van stotteren op participatieniveau door een omgeving te creëren waar stotteren mag, vanaf het begin van de therapie. Mocht het stotteren onverhoopt niet voorbijgaand van aard zijn, dan is er in elk geval wel voor helpende omstandigheden gezorgd waarbij het kind met zelfvertrouwen durft te spreken, ook als er stotters te horen zijn.

Binnen de behandelmethodes RESTART-DCM en Lidcombe Program wordt toegewerkt naar vloeiende spraak (of zo vloeiend mogelijk). In de praktijk blijkt dat ouders het moeilijk vinden dit behandeldoel los te laten, op het moment dat vloeiendheid niet bereikt wordt. Het kan daarom belangrijk zijn om al in een eerder stadium naar ouders te benoemen dat bij sommige kinderen stotteren blijvend kan zijn en dit niet betekent dat het stotteren een belemmering voor het kind is in de rest van zijn/haar leven.

In de praktijk zien we helaas nog met enige regelmaat kinderen die te laat zijn doorverwezen, waardoor de kans op herstel van stotteren veel kleiner is. Ook zien we soms kinderen van een jaar of acht waarbij het behandeldoel nog steeds teveel gericht is op vloeiendheid in spreken in plaats van op communicatieve participatie en tevredenheid over de communicatie in alledaagse situaties. Dit kan zorgen voor teleurstelling in de therapie en een negatieve therapie-ervaring. Omdat er in beide gevallen vaak wel een duidelijke hulpvraag aanwezig blijft, valt het te verwachten dat het kind op een later moment weer in therapie komt. Door de eerdere teleurstelling kan het vervolgens lastig zijn om de ouders en het kind vertrouwen te geven in een positieve therapie-uitkomst waarbij nog (licht) stotteren aanwezig kan zijn, maar het kind niet belemmerd wordt door het stotteren. 


\section{Afsluiten dossier}

Uiteraard wordt het dossier afgesloten als het behandeldoel is behaald. Bij jonge kinderen die stotteren betekent dit dat er geen stotteren meer aanwezig is in het spreken. Bij een hulpvraag gericht op stotteren is het wel belangrijk om nog een aantal maanden controleafspraken te maken om te kijken of het therapieresultaat blijvend is. Hiertoe wordt samen met ouders een terugvalpreventieplan (aanbeveling 17) opgesteld. Hierin staat waarop ouders moeten letten bij terugval, wat ouders dan kunnen doen en in welk geval ouders eerder contact opnemen dan de geplande eerstvolgende afspraak. Tijdens de laatste afspraken wordt de uitvoering van het terugvalpreventieplan besproken en waar nodig bijgesteld. Als het goed is hebben ouders daarna voldoende handvatten om bij een toename in stotterernst adequaat te reageren. Besef dat pas na minstens een jaar volledig vloeiende spraak gesproken kan worden van hersteld stotteren (Ambrose et al., 2015).

Marlies en Joeri zijn beide logopedist-stottertherapeut en behandelen uitsluitend mensen die stotteren en broddelen. Jonge stotterende kinderen maken een groot deel van hun caseload uit. Ze zijn KP en EFS-geregistreerd, lid van de NVLF en NVST, en hebben een praktijk met meerdere logopedist-stottertherapeuten. Ze hebben meegeschreven aan de Richtlijn Stotteren (2020) en hebben de Patiëntenversie van die Richtlijn geschreven.

Marlies Tonnis Stottercentrum Noord marlies@stottercentrumnoord.nl Joeri van Ormondt De Stotterpraktijk joeri@destotterpraktijk.nl 


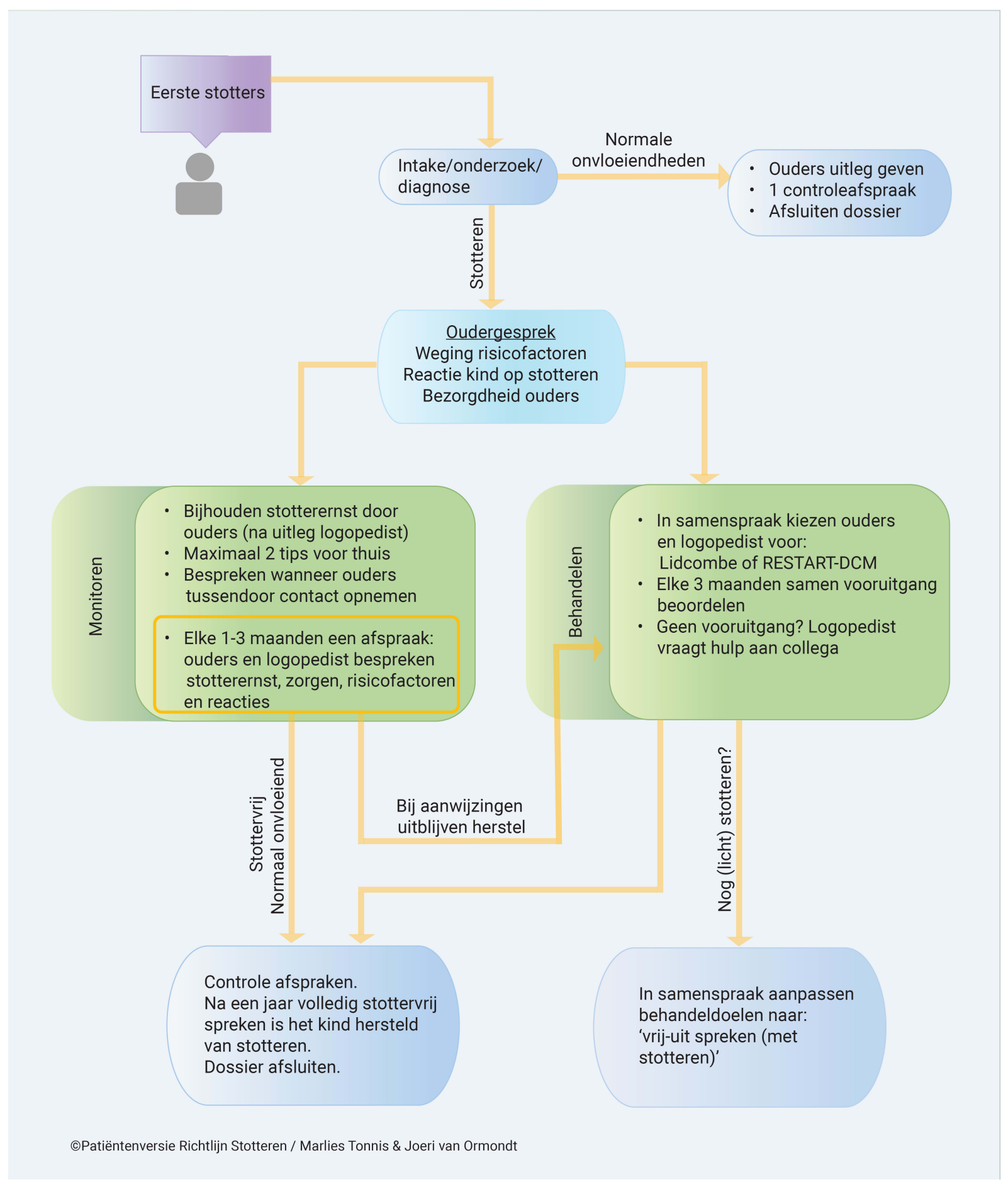

Figuur 1: Stroomschema klinisch redeneren bij jonge stotterende kinderen 


\section{Literatuur}

Ambrose, N. G., Yairi, E., Loucks, T. M., Seery, C. H., \& Throneburg, R. (2015). Relation of motor, linguistic and temperament factors in epidemiologic subtypes of persistent and recovered stuttering: Initial findings. Journal of fluency disorders, 45, 12-26.

Guitar, B. (2014). Stuttering. An integrated approach to its nature and treatment - fourth edition. Lippincott Williams \& Wilkins, Baltimore.

Kelman, E. Nicolas, A. (2020). Palin Parent-child interaction therapy for early childhood stammering - Second edition. Oxon: Routeledge.

NVLF (2020), Richtlijn stotteren bij kinderen, adolescenten en volwassenen, https://www.nvlf.nl/kennis/inhoudelijke-richtlijnen/

Reitzes, P. (2017). Can articulation and phonology treatment lead to stuttering? (Ep. 613). In Stuttertalk: Changing how we think about stuttering...one podcast at a time. http://stuttertalk.com/can-articulation-and-phonology-treatment-lead-to-stutteringep-613.

Rothbart, M. K., Ahadi, S. A., Hershey, K., Fisher P. (2001). Investigations of tem- perament at three to seven years: The Children's Behavior Questionnaire. Child Development, 72, 1394-1408.

Riley, G., Riley, J. (1985). Oral motor assessment and treatment: Improving syllable production. Austin, TX: Pro-Ed.

De Sonneville-Koedoot, C., Stolk, E., Rietveld, T., Franken, M-C. (2015). Direct versus Indirect Treatment for Preschool Children who Stutter: The RESTART Randomized Trial. PLoS ONE 10(7): e0133758. https://doi.org/10.1371/journal.pone.0133758

Tumanova V., Choi D., Conture E.G., Walden T.A. (2018). Expressed parental concern regarding childhood stuttering and the Test of Childhood Stuttering. Journal of Communication Disorders, 72, 8996.

Unicomb,R., Hewat, S., Spencer, E., Harrison, E. (2017) Evidence for the treatment of cooccurring stuttering and speech sound disorder: A clinical case series, International Journal of Speech-Language Pathology, 19:3, 251-264.

Waelkens, V. (2018). Mini-Kids: stottertherapie bij jonge stotterende kinderen. Acco.

Yairi, E., Ambrose, N.G. (2005) Early childhood stuttering. Austin, Tx: Pro-Ed.

Yairi, E., Seery, C.H. (2015). Stuttering. Foundations and clinical applications. Second Edition. Harlow: Pearson. 